
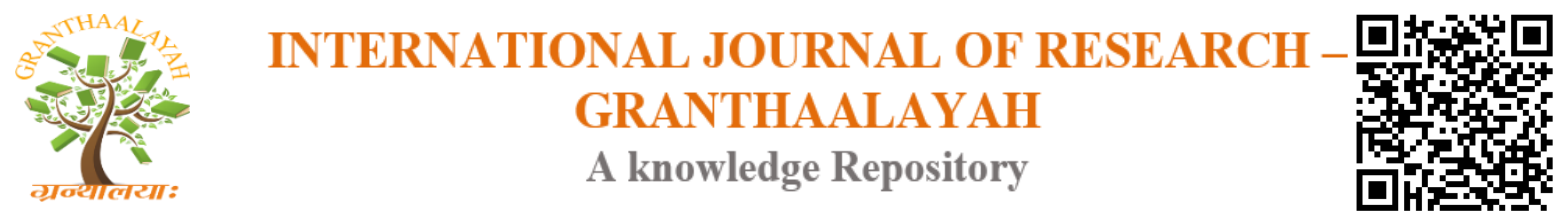

Social

\title{
THE ROLE OF THE AMAIBI IN THE LAI HARAOBA OF MANIPUR
}

\author{
Dr. Salam Shantibala Devi *1 \\ ${ }^{* 1}$ Assistant Professor, Nambol L. Sanoi College, Nambol, India
}

\begin{abstract}
Lai Haraoba is an inseparable part of the cultural life of the Meiteis known as Manipuris in general. It has a dimorigin. Lai Haraoba is a ritual performed under strict rules and order with the objective to please various deities and ancients. During the ritual which may last five days or more, the creation of the world and humans is represented with dance and sing by the maibis accompanied by the pena music of the Maiba. The number of Maibis may vary from three to more than three where only one maiba or Amaiba is employed. There are numerous Umang lais thus to be pleased ritually once in a year. In fact, each place has its own different deity and some particular deities have been regarded as the guardian deity of a region in which all the villages falling inside that region will have to deserve the ritual of lai Haraoba for that particular deity only. This ritual is performed starting on an auspicious day during February to July in a year. The main objectives of Lai Haraoba are to please the deities sot that the area under whose protection becomes prosperous with less morality which also infers the idea of growth of population by reminding people to perform the act of procreation as a duty. This particular part or inducement is performed with beautiful lyrical dialogue on the last day of the ritual in the form of the chance meeting of Panthoibi and Nongpok Ningthou. A propose of what has been laid out above the objectives of the study are very clear. I will help in codifying women's involvement in social and cultural life in Manipur along with its relevant ramifications in the present context. This paper attempt to discuss the importance role of Amaibis in umang Lai Haoba.
\end{abstract}

Keywords: Umang Lai; Maiba Maaibi; Panthoibi; Nonpeak Ningthou.

Cite This Article: Dr. Salam Shantibala Devi. (2018). "THE ROLE OF THE AMAIBI IN THE LAI HARAOBA OF MANIPUR.” International Journal of Research - Granthaalayah, 6(6), 38-44. https://doi.org/10.29121/granthaalayah.v6.i6.2018.1332.

\section{Introduction}

Lai haraoba is an inseparable part of the cultural life of the Meiteis known as Manipuris in general. It has a dimorigin. Lai haraoba is a ritual performed under strict rules and order with the objective to please various deities and ancients. During the ritual which may last five days or more, the creation of the world and humans is represented with dance and sing by the Maibis accompanied by the pena music of the Maiba. The number of Maibis may vary from three to more than three where only one Maiba or Amaiba is employed. There are numerous UmangLai thus to pleased 
ritually once in a year. In fact, each place has its own different deity and some particular deities have been regarded as the guardian deity of a region in which all the villages falling inside that region will have to deserve the ritual of Lai Haraoba for that particular deity only. This ritual is performed starting on an auspicious day during February to July in a year. The main objectives of Lai Haraoba are to please the deities so that the area under whose protection becomes prosperous with less morality which also infers the idea of growth of population by reminding people to perform the act of procreation as duty. This particulars part of inducement is performed with beautiful lyrical dialogue on the last day of the ritual in the form of the chance meeting of Panthoibi and Nongpok Ningthou. A purpose of what has been laid out above the objectives of the study are very clear. I will help in codifying women's involvement in social and cultural life in Manipur along with its relevant ramifications in the present context. This paper attempt to discuss the importance role of Amaibis in Umang Lai Haraoba.

According to some renown scholar, there are four types of Lai Haraoba corresponding to ethnic and geographical distribution of constituent Meitei Communities. The four varieties can be mention as Kanglei i.e. the core Meitei culture based in Imphal and surrounding areas, Moirang including Loktak Lake, Kakching i.e. the Loi Tributary of the Meitei, at Kakching In Thoubal District, and Chakpa i.e. Village tributaries, with the Andro on the eastern foothills of Nongmaijing hills and other peripherally spread Chakpa villages to the north, west and south. The Kanglei Lai Haraoba is regarded as the core ritual, reflecting their belief systems and philosophy.

\section{Types of Lai-Haraoba}

The festival of Lai-Haraoba is observed all over the valley areas of Manipur. The festival of LaiHaraoba is classified into four types i.e.

1) Kanglei Lai-Haraoba

2) Moirang Lai-Haraoba

3) Chakpa Lai-Haraoba and

4) Kakching Lai-haraoba

The festivals performed by the different groups are mainly similar though difference is there in performance. Thus the Amaibi take important role in the four kinds of Lai Haraoba.

Firstly, I have discussed the important role of Amaibi in Kanglei Lai Haraoba.

\section{Kanglei Lai-Haraoba}

There are mainly two opinions amongst the renowned scholars of Manipur regarding the origin of KangleiLaiHaraoba. One group holds the view that Lai-Haraoba was first of all originated from Koubru Hill and their view is said to be based on and ancient Meitei manuscript, Lai-Hoi-Laoba.

Another group of the scholar asserts that Lai-Haraoba was originally started from Langmai Hills (Nongmaijing Hill) during the time of NongpokNingthou and Panthoibi in pre Pakhangba period. They regard Panthoibi Khongkul, an ancient Meitei Text, as the sole authority and as the only source of information concerning the origin of KangleiHaraoba. Kanglei Haraoba is observed most 
of the valley areas of Manipur except Moirang, Kakching and to the place where Chakpa-Haraoba is performed.

The images of which are made of either basket work or wood curved with mask made of brass is called Lai-Phisetpa (to put on dress of deities). This ritual must be performed one day ahead of the festival. After the dressing is over, both Lainingthou (Male deity) and Lairema (Female deity) are then ceremoniously placed on their respective thrones and this is known as Phamdingba. This is also done by the Amaibi.

\section{Lai Ikouba}

The calling of the soul of the deity from a pond or river is one of the most important rituals of the festival of Lai-Haraoba and this is the first item of the occasion/festival.

The people who are taking part in the rituals of Lai Ikouba will line up in a systematic way. In front of the congregational procession of Lai-Ikouba, there are two sword-bearers (bachelors) and they are followed by four girls (in two rows), two of them carrying a Senkha (Pan-box) each and other two a KaoshelHumai (hand fan). In the next row, there are two person known as Lai-Puba (deity bearer), carrying two Laiphees (pitchers) which contains Leiyom. The Ihaiphees tied by a sacred cloth are taken within the folds of an Innafi held by two persons over them. Next comes to women bearing Phida (carpet), over their left shoulders and Sumbals (rice-pounder) in their hands. Then maintaining the order of age (with the enders leading and the younger ones following) congregational procession of the ritual, Ikouba is ready to march towards the ponds or the river where the rite is going to be performed.

Having finished all the ritual items for the procession of Ikouba, the maibi dance Laihou Jagoi (opening dance) with the tune of Pena, drums and flute and along with the Maibas and the Minstrels lead the procession to the river or the pond. Arriving at the bank of the river or the pond, all the participants stand in two rows facing towards the water. The Maiba then performed the ritual of Konyai-Hunba (ritual of offering Gold and Silver pieces). By chanting the Kontharol (a song sung while the rite of Konyai-HUnba is performed), gold and silver coins (which are symbols of earth and sky) are thrown into the water. After this rite, the Amaiba or Amaibi performs the offering of Khayom-Lakpa. The Khayom of male deities known as Nongthak Khayom (Khayom of the sky/heaven) and that of the female deity as Leikha Khayom (Khayom of the below or the earth). This is known as Leithak-Leikha-Lakpa (binding of both heaven and earth together). Prayer is chanted for both Khayoms, when the prayer is over, the two Khayoms are thrown into the water simultaneously.

Then, the Maibi takes the two Ikou-Phu (two pitchers) from the Lai-Pubas-holding that of Laiyingthoi in the right hand and that of the Leirema in the left. She then performed the dance known as Chukpharon-Jagoi and Ihai Jagoi in all four directions namely, the Thangjing, the Marjing, the Wangbarel and Koubru. The Ikou-Phu are then returned to the Lai-Pubas. The Maibi then performed the ritual of Lai-Themgatpa (calling up the spirits of the deities) from the water.

The calling of the deities from the water and placing of Leiyom in the Ikou-Phee is known as LaiLoukhatpa or Ikouba. This follows the returning of the deities back to the shrine and this is called 
Lai Higaba (ascending of the deity). In the course of Lai-Higaba, dances are performed for three times - a dance each in dedication to Laibungthou, Lai-Nura and Leikang-lai. This is known as Khunjao-Leichao-Jagoi (dance of prosperity).

Then the procession is ready to return to the courtyard of the shrine and starts to move towards the courtyards of the shrine and starts to move towards courtyard. When it enters into the courtyard of the shrine. After this, the Maiba takes out the Laiyingthou's Leiyom and Hiri (Strings of sacred thread) from the Ihaiphu (pitcher) and unwinds the thread and the Maibi takes out Lairema's Leiyom and Hiri the holds these. Three men holding the Laiyingthou's Hiri, stand behind the Maibi. Thus, holding the Hiri, all of them simultaneously approached the throne of the Lai (deities) the Maiba holding the Hiri touches the naval of the Laiyingthou and the Maibi that of the Lairema. It is at this time that the infusion/transmission of the soul of the deities into the images of the deities is delivered to have taken place and this ritual is known as Thawai-Happa. The Maiba performed the ritual of Anam-Athou Kokpa (The right of purification) and the Minstrel sings. IkarakpaPhammang-Thougal (a song in praise of the virtues and Chivalries of the deities). Later, the Maibi delivers the oracle. She then performed the ritual of Saroi Khangba (feeding of evil spirits for appeasement). With this ritual performance, the observance of the first day of the festival is over.

\section{Daily Rituals Items}

\section{Yageiba}

In the next morning of the commencement of the festival, the deities are awakening with the singing of Pena by Minstrel. This ritual is known as Yakaiba. This is followed by the delivery of Laipao-Chenba (oracle) by the Maibi. Then, the meal is served to the deities.

In the afternoon, the Maibi initiates the daily ritual with a dance reacted known as Laihou-Jagoi. This is followed by Lei-Langba (offering of flowers). Next comes the ritual Hoi Laoba (shouting of Hoi) by Maiba. The Laibou-Dance and Singing of Anoirol.

Laibou-Dance.

Amaibi performed the Laibou -Dance. Laibou-dance is said to be the most important ritual part of Lai-Haraoba. The Laibou-khuthek or the Laibou-dance demonstrates the birth of a child, construction of a house, plantation of cotton, weaving of clothes and offering of the finished articles to the deities. The Laibou dance consists 364 Khu-Thek (hand movements) and this is known as the Laibou-Khuteks. This type of dance is performed by the Amaibi.

In the Laibou-dance consists of some type of dance known as Hakchang-shaba (creation of a human anatomy) and Yumsharol-Khuthek (dance of house building symbolically). After the finishing of construction of the house and then dedicating it to the deities. Yum-sharol-khuthek is followed by Panthoibi Jagoi. It is a duet dance portraying the romantic affairs between Nongpok Ningthou and Panthoibi.

After the Panthoibi dance is followed by the singing of Paosha (the proverbial song responded one after another) and Anoirol. Next came the Pamyan-Jagoi (a dance showing the act of cultivating land). Pamyan Jagoi is dance which portrays the first cultivation of land by men. It shows the stage of house building, sowing of cotton seeds and weaving of clothes to save from cold. It describes 
the progress of men's civilization which begins with making of cloth and then dedicated it to the deities.

After that Long-Khonba (assort of dance showing the act of fishing with "Long" i.e. a fishing basket made of bamboo) dance which follows Pamyan-Jagoi (a dance showing the act of cultivating land) is another ritual item which is performed on all the spirits of the deities, which are believed to have been playing and returning to the shrine. This is a symbolical presentation for gathering the spirits of deities. It is performed by the Amaibi.

\section{Lairel Mathek}

After Laibou Khuthek, there are following the rituals of Lairel-Mathek chatpa. All the people who participated in the Laibou Dance, stand in one line. A Maiba leads the procession. The procession starts from south west and encircles each of the pillars which signify four directions. The procession moves in such a way that it looks like the moving of a serpent and that is why it is known as Lairel Mathek Chatpa. When the procession reaches the centre of the courtyard where the Laibou-La (plantation leaf) is placed, the Maiba leading the procession touches the last person (of the procession) signifying the head biting the tail of the Lairel paphal. After the dance of LairelMathek-Chatpa next comes the dance of Phibul-Haibi (to play by throwing ball). In this ritual performance a rectangular white cloth is stretched from four decorated poles and each of the four ends of the cloth is help by four persons at the level of the chest. On the outstretched cloth is now placed a bundle containing the Langthrei (a bud of plant) leaves and the bundle is knottel on top at the centre of the out stretched cloth. The two Maibis take out two balls (Phibuls) from the Khudeisels (brass pots) already held by two girls in the procession. The Maibis plays the balls on the outstretched cloth, one Maibi stands near the cloth on the southern side and the other on the northern side. Then the Maibis begin the dance of Chongkhong-Yetpa, Pachurba and ChongkhongLitpa. In these dances, the Maibi's scurry underneath crosswise in between the four Chong-Khongs (Poles) under the outstretched cloth signifying the creation of the Paphal like cobwebs for raising the habilable earth. Thus this ritual dance is performed by the Amaibi.

\section{Kanglei-Thokpa}

Then on the fifth, seventh, ninth and eleventh day of Lai-Haraoba, a ritual part called Kangleithokpa (appearance of Kanglei) is performed. This ritual is performed by Maibi and it depicts the search of a wife by Lainingthou Khoriphaba. The Maibi covering her face with a veil and holding a pole-stick (a style of modern hockey stick made of bamboo stick), hooks a girl from amidst the crowed with a hooked end of the stick (Kangjei). The girl is believed to be the wife of the deity (Khoriphaba). Then she has to come forward and dance with the Maibi. This ritual part is known as Lai-Nupi-Thiba (search of a consort for the deity).

After that, on the last day of Lai-Haraoba festival in the evening, the ritual of the Thang-Thaba (sword dance) performed by two Maibis. One Maibi holds two swords and another one holds two flags. Fire is kept burning in all the four directions/corners of the courtyard. In this ritual, the Maibi's performed the dances of Lairel-Mathek (serpentine pattern) and Hakchang-Shaba (creation of human anatomy). The dance of Hakchang-Shaba is presented in all the four corners of the courtyard. 
Next follows a ritual known as Tangkhul-Thokpa (appearance of Tangkhul). It is a form of dance drama. It describes the meeting of Nongpok Ningthou dressed in a Tangkhul Naga custom and Panthoibi dressed as a Naga girl. It describes their quarrel over a piece of land and then their final reconciliation. Later it follows exchanges of romantic words between the two. The ritual of Ougrihangu comes after the ritual of Tangkhul-Thokpa. In this ritual, a rope which has been kept near the deity on a Langthrei of men and women. The two ends of rope is tied and hand bell of the Maibi is also tied to the rope. As soon as the singing of Ougri starts, no one should let go the rope of one's hands and there shall not be ant movement. The signing of Ougri is believed to be for the welfare and prosperity of the concerned locality or village. After that there follows the performance of the rituals, like Thawai-mi-kouba (the gathering of souls), Huithi-Yenthi-Yeppa and Sharit-litpa with this, the ritual of Ougri-Hangel-Chongba comes to an end.

Next is the singing of Khenso, Paosha, Hijen-Hirao and Uyallon. Then, comes Lai-Nongaba (return of the deities back to heaven). After this, the ritual of Lai-Tethaba (apartment of the deities) is performed. The Maibi then performs the rite of Saroi-Khangba (feeding of evil spirits). Here ends the ritual of Lai-haraoba.

\section{Conclusion}

In Manipur with the influence of Hindu Vaishnavism, there was a great religious upheaval changes in the Meitei community even though the festival of Lai-Haraoba still remains distinctly a Meitei culture. This religious influence is mostly confined to outer forms such as dress, offering of fruits and vegetables in place of animal's sacrifices etc. However, it should be noted that these changes in dress and offering to the traditional duties due to influence of Hinduism do not apply to Chakpa Haraoba. They still continued to pressure the traditional culture and religion. During the ritual observance of Lai-Haraoba. The people of Andro, Phayeng and others Chakpas inhabited places still put an traditional dress and they don't put on the Chandan mark on their face. Above all animals sacrifices is still very much practiced.

From the Above approach, I have found the role of Amaibi is dutiful in the Kanglei Lai-Haraoba festival from the beginning to the beginning of the festival, further the role of Amaibi to the Moirang Haraoba and Chakpa Lai Haraoba except Kakching Haraoba. I have found the role of Amaibi is so dutiful form the beginning to the end of the Lai Haraoba Festival. In this connection Moirang Haraoba and Chakpa Haraoba are also mainly observed by the Lai Shelungba except dancing. Dancing is all are performed by the Amaibi. The delivery of Laifao (aracle) by the Maibi offering of Flower and fruits to the deities are performed by the Thougal Langla and Lai Shelungba known as Laishangba.

Among the Four kinds of Lai-Haraoba chakpa Haraoba at Andro is different one from others. Why so said is that the Lairenmathekseen Kakching, Moirang and Kanglei, it is not found in Andro.

From the ancient period our society is a patriarchal society men dominated society but in the ritual ceremony women is mainly observed as dutiful. The main example is the role of Amaibi in Lai Haraoba and other ceremonies we have. 
The different segments of the festival are presented as Maibi Laiching Jagoi, Thougal Jagoi and so on. The most important segment of the festival is Lai Ikouba. In this segment the main performance and deities of to please the duties is performed by the Amaibi. It is so long in the festival there is no part without Amaibi Until to the end of the Lai-Haraoba festival.

In the society woman is so important part of the family for which is contributed the nation is to develop and uplift in many faced. The role of Amaibi is still remain with Lai-Haraoba festival so long period from the time immemorial to the beyond of generation to generation. It may be observed in the places where the Manipuris settle in India and abroard.

\section{References}

[1] Chandra singh, M. Panthoibi Khongul, Imphal, 1999.

[2] Chandramani Singh, Barak Tampakta Lai-Haraoba (Lai Haraoba at Barak Valley) Ph.D. Thesis , Manipur University, 1997.

[3] Hudson, T.C The Meithei, Low price Pub, Delhi,1997

[4] Indira E, Lai Haraobagi Wakhallon Paring, Imphal, 1993

[5] Khelchandra, Ng. Meitei Lai Haraoba, Imphal 1963.

[6] Kulachandra Singh, Lai Haraobagi Hourakpham, Imphal,1980

[7] Nodia Ngangoicha, Moirang Kangleirol Lambuba

[8] Rajen, T., Lai-Haraoba, Traditional theatre Ama Oina Neinaba, Ph.D Thesis, Manipur University, 1995

[9] Ratan Kumar, Kh. The Lai-Haraoba of Manipur (A social, cultural and historical study) Ph.D Thesis, Manipur University, 1993

*Corresponding author.

E-mail address: salamsantibala1122@gmail.com 